\title{
The Role of the Kolbuszowa Folk Culture Open-Air Museum in Studies of Traditional Wooden Architecture of the Rzeszowiacy Ethnographic Group
}

\section{Tomasz Tomaszek}

Tomasz Tomaszek, Dr

University of Technology Rzeszow

Faculty of Civil and Environmental Engineering and Architecture

Department of Monuments Conservation

al. Powstańców Warszawy 12

35-959 Rzeszów

Poland

e-mail: ttomasz@prz.edu.pl

$\&$

Regional Architecture Documentation Studio

the Folk Culture Open-Air Museum in Kolbuszowa, ul. Wolska 36

36-100 Kolbuszowa

Poland

e-mail: architektura@muzeumkolbuszowa.pl

ORCID: 0000-0003-3529-7775

Muzeológia a kultúrne dedičstvo, 2021, 9:3:43-63

DOI: $10.46284 / \mathrm{mkd} .2021 .9 .3 .3$

The Role of the Kolbuszowa Folk Culture Open-Air Museum in Studies of Traditional Wooden Architecture of the Rzeszowiacy Ethnographic Group

The "Rzeszowiacy" ethnographic group inhabits the central and northern part of the Podkarpackie Province, which is located in the south-eastern corner of Poland. At the beginning of the 1970s, as the result of an initiative drawing attention to the need for documentation of the rapidly disappearing traditional Rzeszowiacy vernacular wooden architecture (and that of the neighboring ethnographic group, the Lasowiacy), the Folk Culture Open-Air Museum in Kolbuszowa was created. This paper presents a short overview of the open-air museum's establishment and describes in detail its role in the study and protection of the wooden architectural heritage of the Rzeszowiacy ethnographic group, based on the museum's research, carried out over fifty years, and its collection of buildings.

Keywords: wooden vernacular architecture, Rzeszowiacy ethnographic group, open-air museum

\section{Introduction}

The idea of establishing open-air museums was born as a result of rapid social and cultural changes across Europe during the second half of the nineteenth century. The recognition of folk culture as an essential conveyor of tradition was motivated by the period's progressive industrialisation and increased interest in the past and the national identity of individual ethnic groups. ${ }^{1}$ The first ethnographic park was established in Stockholm in 1891 by Artur Hazelius, ${ }^{2}$

\footnotetext{
${ }^{1}$ SPISS, Anna. Muzea etnograficzne na wolnym powietrzu w Europie. In: Biblioteka Muzealnictwa i Ochrony Zabytkón. Studia i Materialy, 2, 1985, p. 11.

${ }^{2}$ RENTZHOG, Sten. Open Air Museums - the History and Future of a Visionary Idea. In: European Journal of Archaeology, 11(2-3), 2008, p. 313.
} 
while the first institution of this type in what is now Poland was established in 1906 in Wdzydze Kiszewskie by the Gulgowski family. ${ }^{3}$

Open-air museums established in the first half of the twentieth century in Poland were primarily characterised by the application of a so-called "park layout". Initially, only the most representative buildings were collected and exhibited in a loose compositional layout and framed by loosely arranged greenery. ${ }^{4}$ The exhibition of entire settlement layouts with farm buildings started to appear later. ${ }^{5}$ This tendency slowly began to change during the interwar period, when open-air museums began to exhibit "average" buildings that were relocated there, which were seen as typical for a given ethnographic group within a given timeframe. ${ }^{6}$ The development of open-air museum institutions in Poland was particularly observable in the second half of the twentieth century. The open-air museums opened during this period were divided into sectors that presented individual ethnographic groups from a given region of Poland. When organising the composition of the relevant buildings, care was taken to fragmentarily reconstruct the spatial structure and terrain conditions similar to the natural and cultural environment of the exhibited ethnographic group. ${ }^{7}$ This type of exhibition is currently presented by most openair museums that now exist in Poland. ${ }^{8}$ The concept of creating open-air museums was also affected by changes in the approach to conservation towards the end of the 1960s, when it became popular to protect the cultural landscape understood as the human environment. Since then, numerous new spatial layouts that holistically reconstruct the historical space of rural settlements have been introduced into open-air museums in Poland.

The open-air museum in Kolbuszowa was established at the start of the 1970s as a result of an initiative which stressed the necessity to document and protect the rapidly disappearing traditional vernacular folk architecture of the central and northern parts of the Podkarpackie Voivodeship (or Podkarpackie Province, also known as Subcarpathian Voivodeship), an area that is in Poland's south-eastern corner. ${ }^{10}$ At the same time, the open-air museum was to present the most valuable specimens of vernacular architecture in museum conditions, collected from territories inhabited by the Lasowiacy and Rzeszowiacy ethnographic groups.

Since its establishment, the open-air museum in Kolbuszowa — apart from collecting exhibits showing the material heritage of ethnographic groups from the central and northern part of the Podkarpackie Voivodeship, primarily comprised of vernacular folk architecture-began sophisticated field work associated with studying and documenting the traditional wooden architecture of this territory. This paper presents a short overview of the open-air museum's

\footnotetext{
${ }^{3}$ SPISS, Muzea etnograficzne..., pp. 33-34.

${ }^{4}$ PRARAT, Maciej. Koncepcja Olęderskiego Parku Etnograficznego w Wielkiej Nieszawce. Głos w dyskusji o roli skansenów w ochronie zabytków architektury drewnianej. In: Ocbrona Zabytków, 1-4, 2013, p. 239.

${ }^{5}$ SPISS, Muzea etnograficzne..., pp. 59-61.

${ }^{6}$ Ibid. p. 61.

${ }^{7}$ GINALSKI, Jerzy, OSSADNIK, Hubert. 50 lat Muzeum Budownictwa Ludowego w Sanoku w świetle archiwaliów. In:Materiaty Muzeum Budownictwa Ludowego w Sanoku, 37, 2008, p.13.

8 ŚWIECH, Jan, TUBAJA, Roman. Historia idei muzealnictwa na wolnym powietrzu w Polsce. In: Biuletyn Stowaryyszenia Muzeón na Wolnym Powietrzu w Polsce, 9, 2006, p. 61.

${ }^{9}$ SZMYGIN, Bogusław. Ksqtałtowanie koncepcji zabytku i doktryny konserwatorskiej w Polsce w XX wieku. Lublin: Wydawnictwo Politechniki Lubelskiej, 2000, p. 201.

${ }^{10}$ In the period of the establishment of the Folk Culture Open-Air Museum in Kolbuszowa, the areas in question were administratively a part of the erstwhile Rzeszowskie Voivodeship, which was divided into several smaller administrative units in 1975. In 1999, the area that had belonged to the Rzeszowskie Voivodeship was once again merged into a single administrative unit, which was renamed to the Podkarpackie Voivodeship.
} 
establishment and characterises the wooden architectural heritage of the Rzeszowiacy ethnographic group based on the current collection and research carried out over the fifty years of the existence of the Folk Culture Open-Air Museum in Kolbuszowa.

\section{Origins of the Kolbuszowa Open-Air Museum}

Multi-directional efforts to establish an open-air museum that would protect the traditional vernacular wooden architecture of the Lasowiacy and Rzeszowiacy had been made already since the end of the 1960s. An intensification of this activity took place in the period between October 1970 and the beginning of 1972. It was significant that a community museum that collected the legacy of the folk culture of the Lasowiacy had existed in Kolbuszowa since 1959, established with the support of a group of regionalists with particular activity shown by Doctor Kazimierz Skowroński. ${ }^{11}$

The idea to establish the open-air museum in Kolbuszowa was actively supported by a group of ethnographers and conservators interested in the conservation of folk architecture. These included Jerzy Tur (the Voivodeship Conservator of Historical Monuments up to 1967 and an employee of the District Museum in Rzeszów since 1968), Inga Sapetowa, the Voivodeship Conservator of Historical Monuments from 1967, Barbara Tondos from the Historical Monuments Documentation Office in Rzeszów, and Andrzej Karczmarzewski and Teresa Szetela-Zauchowa from the Ethnographic Department of the District Museum in Rzeszów.

The land for the open-air museum was initially chosen at the start of October 1970. It was a site with an area of around 30 ha, located on the outskirts of Kolbuszowa. The site was crossed by a small creek that flowed around the remains of a pond overgrown with trees and bushes that belonged to the State Fishing Farm and had been unused for years. Most of the area comprised flat farmland and wasteland covered with patches of heather that stretched towards the buildings of the nearby village of Domatkowa, visible in the distance, and it was divided in places by patches of pine and birch trees. During the first visit to the site, a team of project stakeholders that included K. Ruszel, J. Tur, T. Szetela-Zauchowa, A. Karczmarzewski, and Doctor K. Skowroński proposed to divide its entirety into three main sectors in accordance with the character of the territories inhabited by the ethnographic groups the museum was to represent. And so, the fields and wasteland were assigned for the buildings of the Lasowiacy and the slightly elevated and clearly separated section to the south of the pond was assigned for the buildings of the Rzeszowiacy, while the remaining area was to provide necessary infrastructure. ${ }^{12}$ This established the open-air museum's general development and arrangement plan, which has survived unchanged to this day.

The aforementioned initial activity associated with the organisation of the open-air museum in Kolbuszowa caused the authorities to issue an official decision about the planned establishment

\footnotetext{
${ }^{11}$ The idea behind the establishment of the Folk Culture Open-Air Museum in Kolbuszowa was to protect the material heritage of the Lasowiacy and the Rzeszowiacy and to study their tangible and intangible culture, customs, language, etc.

${ }^{12}$ RUSZEL, Krzysztof. Zanim powstał skansen-czyli kształtowanie się koncepcji oraz starania o utworzenie w latach 1970-1972. In: Jacek Bardan, Katarzyna Dypa (eds.). Biuletyn Jubileuszowy Muzeum Kultury Ludowej w Kolbuszowej. Kolbuszowa: Wydawnictwo Mitel, 2009, p. 18.
} 
T. Tomaszek.: The Role of the Kolbuszowa Folk Culture Open-Air Museum in Studies...

of a new ethnographic park in what was then the Rzeszowskie Voivodeship. ${ }^{13}$ The first stage was the nationalisation of the previous community museum on 1 January 1971 and its renaming to the Regional Museum of Kolbuszowa. Among the tasks given to the institution, the most important ones included the preparation of a proposal of general concept, and performing work associated with establishing an open-air museum presenting the folk architecture of the Lasowiacy and Rzeszowiacy. In February 1972, the design of the open-air museum in Kolbuszowa was presented to Stanisław Brzostowski (director of the Board of Museums and Monuments Protection of the Ministry of Culture and Art) and to Professor Józef Burszta (the Head of the Department of Ethnography at the A. Mickiewicz University in Poznań). After the nationalisation of the Regional Museum devoted to Lasowiacy in Kolbuszowa, duties for establishing the open-air museum were taken over by Maciej Skowroński, who was assigned to direct the new institution in $1972 .{ }^{14}$

In the late autumn of 1970 and the winter of 1971, field research began along with reconnaissance for buildings suitable for relocation to the open-air museum. At the time, the reconnaissance covered the northern area of the Vistula and San river forks, associated with the Lasowiacy ethnographic group, and the lands south of this area associated with the Rzeszowiacy ethnographic group. The results of site visits were not exceedingly optimistic. A considerable portion of the historical vernacular architecture that had been recorded already during ethnographic studies in the 1960s had been demolished or considerably remodelled. The scholars also often arrived precisely at the moment when historical cottages or outbuildings were being demolished. One such instance was the demolition of an old village inn in Racławice near Nisko. ${ }^{15}$ The search for complete farms (group of outbuildings belonging to one farm) proved fruitless and resulted in the depressing vision of it becoming necessary to reconstruct them, i.e. pair together buildings that had belonged to different owners/farms, or in some cases had been located in different or faraway villages.

The first building purchased for the Kolbuszowa open-air museum was a wagon shed from Grzęska, from the Przeworsk District. Its owner had pressured the museum to collect the building as he had built an impressive new outbuilding near the wagon shed. The building was dismantled in July 1971 by a team of employees of the District Museum in Rzeszów that included a carpenter, two drivers, and a warehouseman. ${ }^{16}$ The disassembled material was stored for a considerable period of time in a space used by "Polskie Pracownie Konserwacji Zabytków"17 in Jarosław and was then transported to Kolbuszowa, where it unfortunately

\footnotetext{
${ }^{13}$ The Open-Air museum in Kolbuszowa was established as the second ethnographic park in the contemporaneous Rzeszowskie Voivodeship (the present-day Podkarpackie Voivodeship). The first was the Open-Air Museum in Sanok, which was established after the Second World War. It displays collections belonging to the Pogorzans (Walddeutsche), Dolinianie, Lemkos, and Boykos. It is also the largest ethnographic museum in Poland in terms of the number of buildings.

14 SKOWROŃSKI, Maciej. Tak się zaczęło... — czyli o początkach i pierwszych latach Muzeum w Kolbuszowej. In: Jacek Bardan, Katarzyna Dypa (eds.). Biuletyn Jubileuszony Muzeum Kultury Ludowej w Kolbuszowej. Kolbuszowa: Wydawnictwo Mitel, 2009, p. 14.

${ }^{15}$ RUSZEL, Zanim powstał skansen..., p. 20.

${ }^{16}$ LEW, Stefan. Wędrówka_czyli rzecz o pierwszym zabytku w Parku Etnograficznym. In: Jacek Bardan, Katarzyna Dypa (eds.). Biuletyn Jubileuszowy Muzeum Kultury Ludowej w Kolbuszowej. Kolbuszowa: Mitel, 2009, p. 25.

17 "Polskie Pracownie Konserwacji Zabytków" (equivalent to: "Monuments Conservation Workshops in Poland")—a state enterprise established by the order of the Minister of Culture and Art on August 25, 1950 in order to conduct research on monuments, to document them and to carry out restoration and conservation works on immovable and movable monuments, as well as to conduct archaeological research.
} 
burned down as a result of an accidental fire. ${ }^{18}$ Thus, the Kolbuszowa open-air museum was left without the first building purchased with the intent to establish it.

In the first half of 1971, a building survey of a historical windmill located in Trzęsówka was concluded. It later became one of the first buildings to be relocated to the Kolbuszowa open-air museum. Additionally in 1971, an inspection and assessment of a watermill and an adjacent miller's house in Żołynia was performed. They were slated for transfer to the openair museum in Kolbuszowa. Unfortunately, only the mill was relocated to the museum and the miller's house remained at its original site for reasons that are difficult to establish nowadays. Another building from Żołynia that was disassembled by the team from the Regional Museum in Kolbuszowa in July 1973 was a historical house from 1815, which had stood on a dangerous turn along the road from Lańcut to Leżajsk and was thus often called "zawalidroga" (equivalent to "road hog" in Polish). ${ }^{19}$

Studies and building surveys of cottages and outbuildings prepared by students of the Cracow University of Technology proved to be a great aid in identifying the condition of folk architecture during the initial period of the open-air museum's establishment. They were performed during a research trip that took place towards the end of June and the beginning of July 1971 on the initiative of the Faculty of Architecture of the Cracow University of Technology. The students were tasked to identify wooden buildings for detailed building surveys and conduct ethnographic interviews. ${ }^{20}$ This initiative became the commencement of extensive study of the vernacular architecture of the Rzeszowiacy and Lasowiacy, which is being successfully carried out by the Open-Air Folk Culture Museum in Kolbuszowa to this day.

\section{The Rzeszowiacy ethnographic group}

The Rzeszowiacy inhabit the southern area of the Sandomierz Basin, which is located in the Podkarpackie Voivodeship that occupies the south-eastern edge of Poland. Their settlements are located primarily along a wide strip of fertile loess land located on both sides of the central and lower section of the River Wisłok and are grouped around three cities: Rzeszów, Lańcut and Przeworsk. ${ }^{21}$ It should be noted that some scholars extend the area inhabited by the Rzeszowiacy westwards to the town of Ropczyce, and eastwards to the area of Jarosław. ${ }^{22}$

Good climate conditions and placement at the foot of the Sandomierz Basin, which had been covered by dense and very old forests, proved conducive to settlement. Over time, the forests were largely cleared and their place was taken by fertile loess soil used for agriculture. The area's geopolitical location also proved essential to its rapid development and the emergence of the local culture. ${ }^{23}$ The land occupied by the Rzeszowiacy was crossed by important medieval transport and trade routes. The most significant of these included those that led eastwards (from Silesia via Cracow, Rzeszów, and Lviv to the Black Sea) and those that led southwards

\footnotetext{
${ }^{18}$ RUSZEL, Zanim powstał skansen..., p. 21.

${ }^{19}$ SKOWROŃSKI, Tak się zaczęło..., p. 14.

${ }^{20}$ RUSZEL, Zanim powstał skansen..., p. 22.

${ }^{21}$ DRAGAN, Wojciech. Budownictwo drewniane w dorzeczu środkowego Wisłoka. In: Katarzyna Barańska, Jolanta Dragan (eds.). Folklor Rzeszowiakó-obrazprzemian wedtug badań terenowych 2014-2016. Kolbuszowa: Zakład Poligraficzny Zdzisława Gajek, 2018, p. 241.

${ }^{22}$ KOTULA, Franciszek. Strój rzeszowski. In: Atlas Polskich Strojów Ludowych, 3(5): Małopolska. z.13, 1951 , p. 11.

${ }^{23}$ DRAGAN, Budownictwo drewniane..., p. 241.
} 
(from Sandomierz through the Carpathian basins to Slovakia and Hungary). ${ }^{24}$ Citing Dragan, ${ }^{25}$ mentions of the historical routes were found in oral accounts obtained during field research in the land around Rzeszów that were conducted by the Folk Culture Museum in Kolbuszowa: "Kosina began at Klin, the Cracow-Lviv route crossed there, before road number four was built in the Austrian times. The Sieniawa route ran behind the tracks between Kosina and Głuchów."26

\section{Etymology of the name Rzeszowiacy}

The cultural distinctiveness of the Rzeszowiacy developed over the course of a centurieslong process of historical and social transformations. The territory they inhabited at least since the early Middle Ages was a contested borderland between Poland and Red Ruthenia. It was thus settled by Slavic people who came here both from the west and the east. ${ }^{27}$ This was facilitated by the active resettlement policy practiced by both states, offering settlers years of tax exemptions and other privileges. ${ }^{28}$

According to Dragan, ${ }^{29}$ the first to observe the cultural distinctiveness of the area's population was J.S. Bystron, who called it the Rzeszowiacy in an ethnographical division compiled in 1925. The name was based on the city of Rzeszów - the centre of the area. ${ }^{30}$ According to Bystron, it was a secondary ethnographic group (as opposed to a primary, tribal group), counted among the eastern borderland groups of Poland: "And another group is set aside, namely the Rzeszowiacy. Here we are also dealing with a borderland that, despite being a direct eastwards extension of Lesser Poland, has developed separately. By the name Rzeszowiacy [...] we distinguish the native, long-since settled Polish population of the western Ruthenian Voivodeship."31

According to Dragan, the name Rzeszowiacy was coined for classification purposes from an ethnographic perspective and not out of a sense of group distinctiveness or identity of the population of the microregion. ${ }^{32} \mathrm{~K}$. Ruszel noted that the character of J.S. Bystron's phrase (analogous to the naming of other ethnographic groups on the basis of large urban centres, such as the Sandomierzanie, Lubliniacy, Krakowiacy) allows us to assume that the name Rzeszowiacy, used to describe the ethnographic group prevalent in the area, could have been in use in the 1920s, i.e. during the period when Bystron recorded the classification. ${ }^{33}$

\footnotetext{
${ }^{24}$ KARCZMARZEWSKI, Andrzej. Rzeszowiacy. Charakterystyka regionu. In: Alicja Haszczak (ed.). Tańce rzeszowskie. Rzeszów: PHU Mitel, 2012, p. 10.

${ }^{25}$ DRAGAN, Budownictwo drewniane..., p. 241.

${ }^{26}$ Kosina, TT, MKL-AE 651/6. (This abbreviation denotes the following: Kosina—place name; TT-initials of the person giving the account in a field interview [the "informant"]; MKL-AE 651/6 —stock number/interview documentation signature as listed in the archives of the Folk Culture Museum in Kolbuszowa. The marking system is used in this form throughout the following part of the text. The first part—-the name of the location—is the place where the field interview took place or the place where a specific structure was located).

${ }^{27}$ DRAGAN, Budownictwo drewniane..., p. 238.

${ }^{28}$ ZUBRZYCKI, Denys. Granice miedzy Ruskimi polskim narodem w Galicyi. Lwów, 1848, p.4.; KOTULA, Franciszek. Geneza regionów etnograficznych woj. Rzeszonskiego. Mielec, 1968, p. 8.

${ }^{29}$ DRAGAN, Budownictwo drewniane..., p. 238.

${ }^{30}$ BYSTROŃ, Jan Stanisław. Nazwy i przezwiska polskich grup plemiennych i lokalnych. In: Prace i Materiaty Antropologiczno- Archeologiczne i Etnograficzne, 4(3), 1925, p. 101.

${ }^{31}$ BYSTROŃ, Jan Stanisław. Ugrupowania etnične ludu polskiego (Les groupes ethnographiques polonais). Kraków: Orbis, 1925, p.17.

${ }^{32}$ DRAGAN, Budownictwo drewniane..., p. 240.

${ }^{33}$ RUSZEL, Krzysztof. Z badań nad kulturą ludową Rzeszowiaków. In: Prace i Materiaty z Badań Etnograficznych, 5, 1985, p. 9.
} 
The term "Rzeszowiacy" proposed by Bystron is still in popular use today. ${ }^{34}$ However, it should be highlighted that despite its limited territorial scope, and relatively similar natural conditions and a comparable socio-economic situation and history, this group does not form a cultural monolith. Cultural variation within the entire group of the Rzeszowiacy was postulated by, among others, A. Saloni (late nineteenth and early twentieth century) ${ }^{35}$ or F. Kotula (twentieth century), ${ }^{36}$ proposing its division into three subregions: Rzeszów, Łańcut, and Przeworsk.

The Rzeszowiacy are also not a group that is fully ethnically homogenous, as noted by D. Zubrzycki ${ }^{37}$ and F. Kotula. ${ }^{38}$ Numerous scholars have claimed that the Rzeszowiacy as an ethnographic group developed from a mixture of settled Polish and Ruthenian populations as well as German colonists. This is corroborated by the presence of German settlers in the area who are called Głuchoniemcy (also Walddeutsche)..$^{39}$ They had a significant and crucial impact on the material culture of the Rzeszowiacy, especially their agriculture and architecture (particularly the Rzeszowiacy from the Lańcut and Przeworsk groups). ${ }^{40}$ The beginnings of this colonisation reach back to the first half of the fourteenth century, when Red Ruthenia was permanently incorporated into the Crown of the Kingdom of Poland by Casimir the Great. German settlement of the land around Rzeszów was initiated by Władysław, governor of Red Ruthenia and prince of Opole, who brought settlers from Silesia, Lusatia, and Saxony to the area. The newcomers were to aid in rebuilding the damage wrought upon the territory during previous military operations. However, it should be mentioned here that this colonisation was not always explicitly associated with Germans. Kotula argued that, despite being germanised, they were Silesians or west Slavic settlers. ${ }^{41}$

The settlers who came from the west and who then inhabited previously sparsely populated land brought with them notions of an organised development system and a new legal order. Historical texts from the middle of the seventeenth century include the following accounts:

\begin{abstract}
Next is Lańcut [...] and Rzeszów [...]; the area is usually abundant with milk and linen fabric, as all of its villages are inhabited by descendants of the German tribe [...] brought here from Saxony, with children and wives, out into these parts. They take great care in the husbandry of cattle and cultivation of linen and, during market, take their goods for exchange to nearby cities, primarily to Rzeszów and Jarosław. ${ }^{42}$
\end{abstract}

\footnotetext{
${ }^{34}$ DRAGAN, Budownictwo drewniane..., p. 240.

${ }^{5}$ SALONI, Aleksander. Lud rzeszowski. In: Materyaly Antropologiczno-Archeologiczne i Etnograficzne, 10, 1908, pp. 273-568; SALONI, Aleksander. Lud wiejski w okolicy Przeworska. In: Wisła: Miesięcznik geograficzno-etnograficzny, 11, 1897, pp. 738-759; 12, 1898, pp. 47-64; 719-748; SALONI, Aleksander. Lud łańcucki. Materyały etnograficzne. In: Materyaly Antropologiczno-Archeologiczne i Etnograficzne, 6, 1903. pp. 187-204.

${ }^{36}$ KOTULA, Geneza regionów..., p. 8.

${ }^{37}$ ZUBRZYCKI, Granice miedsy..., p. 4.

${ }^{38}$ KOTULA, Genez̧a regionów..., p. 8.; ZUBRZYCKI, Granice między..., p. 8.

${ }^{39}$ KARCZMARZEWSKI, Rzeszowiacy..., p. 10.

${ }^{40}$ DRAGAN, Budownictwo drewniane..., p. 239.

${ }^{41}$ KOTULA, Geneza regionów..., p. 9.; TEJCHMA, Józef. Dawniej. O ludziach i czasach w Markowej. Markowa, 2008, pp. 18-19; KARCZMARZEWSKI, Rzeszowiacy..., p. 10.

${ }^{42}$ STAROWOLSKI, Szymon. Polska albo opisanie położenia Królestwa Polskiego w Kolonii u Henryka Krithiusa roku 1632. (Translation: Piskadło Andrzej). Gdańsk: Wydawnictwo Literackie, 2000, p. 79.
} 
In the new conditions of the territory in question, multiple ethnicities coexisted together and so did their traditions and cultural patterns. Over the many centuries of coexistence, differences slowly disappeared and German as a language ceased to be used. This process was not uniform, as evidenced by the dominance of the settlers' original language for several centuries after their arrival to the area around Rzeszów. As argued by Dragan, ${ }^{43}$ one example of this could be the village of Markowa, where-despite the disappearance of differences between the German and Polish population - all documents had been exclusively developed in German up to the seventeenth century ${ }^{44}$ and the language of the settlers' former fatherland could be heard there as late as in the nineteenth century. This is attested to by an account from the nineteenth century that reported that Markowa's peasants had been mixing German phrases with Polish ones, and during holidays sang songs "in an incomprehensible language, perhaps broken German". ${ }^{45}$

Here it should also be added that the character of the area was affected by the late-medieval settlement of Wallachian shepherds. ${ }^{46}$ Citing Dragan, ${ }^{47}$ the studies performed by the Folk Culture Museum in Kolbuszowa did not yield convincing data as to their contribution to village organisation or architecture in the area in question. However, it is known from the literature that villages founded on the basis of Wallachian law were sited in areas with gaps in settlement, where settled agriculture was thus initiated. ${ }^{48}$ These villages had chain-type layouts and were founded where villages based on German town law and thus featuring a łan-type (plot arrangement-based) field system had proved unsuccessful. In the area in question, the only village to have a confirmed foundation based on Wallachian law is Hadle Szklarskie. ${ }^{49}$ Citing Persowski, it can also be observed that Wallachian law was used in the village of Markowa (here it functioned either earlier to or in parallel with the Magdeburg law). ${ }^{50}$

\section{Studies on the wooden architecture legacy of the Rzeszowiacy}

One of the main indicators of any ethnographic group's distinctiveness, apart from attire, customs and speech, is architecture. The specimens of the architecture of the Rzeszowiacy exhibited at the Kolbuszowa Open-Air Folk Culture Museum are the only collection of historical buildings of this type to be featured in museum conditions in Poland. At the same time, this collection can be considered a summary of long-term studies by the Folk Culture Museum in Kolbuszowa on the architectural traditions of the Rzeszowiacy.

Field studies have been carried out for many years in villages around Rzeszów, Łańcut, and Przeworsk (villages located in the Rzeszów, Lańcut, and Przeworsk districts), excluding the

\footnotetext{
${ }^{43}$ DRAGAN, Budownictwo drewniane..., p. 239.

${ }^{44}$ Ksiega sadowa wsi Markowa, Archive of the CPAHU in Lviv, 1591-1777, fond 85, description 1, volume 1, manuscript. Copy stored at the archives of Towarzystwo Przyjaciół Markowej in Markowa.

${ }^{45}$ Stownik Geograficæny Królestwa Polskiego i krajów stowiańskich. 1880-1914. Vol. 6. (ed. Franciszek Chlebowski; Władysław Walewski). Warszawa: Nakładem Filipa Sulimierskiego i Władysława Walewskiego, 1885, p. 126.

${ }^{46}$ KOTULA, Geneza regionów..., p. 8.; LEW, Stefan. Budownictwo ludowe dorzecza Sanu w XIX $i$ XX wieku. Rzeszów: Mitel, 2003, p. 27.

${ }^{47}$ DRAGAN, Budownictwo drewniane..., p. 240.

${ }^{48}$ JAWOR, Grzegorz. Osady prawa wotoskiego i ich miesz̨ańcy na Rusi Czerwonej w późnym średniowieczu. Lublin: Wydawnictwo Uniwersytetu Marii Curie-Skłodowskiej, 2000, p. 167.

${ }^{49}$ Akta grodzkie i ziemskie z czasów Rzeczypospolitej Polskiej z archiwum tak zwanego bernardyńskiego we Lwowie w skutek fundacyi śp. Alexandra br. Stadnickiego, vol. 7, Lwów 1878, p. 22.

${ }^{50}$ PERSOWSKI, Franciszek. Księga sądowa wsi Markowej w powiecie przeworskim. In: Roczniki Driejów Społecznych i Gospodarczych., 1, 1931, p. 47.
} 
villages located the closest to Rzeszów, which are currently largely incorporated into the city's administrative limits. ${ }^{51}$

Significant pieces of information concerning architecture were procured via direct interviews. Many of the interviewees had been born prior to or during the Second World War and thus were able to observe and personally experience the relevant transformations in all fields of life, including architecture. The information they provided also included their personal opinions about this process. $^{52}$ In most cases, the information concerning architecture was mentioned in the context of the changes that had allowed the respondents to improve their housing and existential conditions over the post-war years.

Unfortunately, the scant amount and laconicism of the accounts that directly referred to architecture, farms and houses resulted in the necessity to reference earlier field studies and the pre-existing literature.

As noted by Dragan, ${ }^{53}$ despite settlement continuity in the area in question, two distinctive time periods with considerable differences in architecture can be observed. And so, up to the 1950s and 60s, buildings were built and finished largely traditionally (Jawornik Polski, Wólka Podleśna, Zabajka). ${ }^{54}$ Afterwards, from the 1960s (and lasting mostly until the 1990s — the start of profound social changes in Poland) many informants juxtaposed traditional architecture with masonry buildings that they saw as better and more modern, and it was considered to change the face of rural areas:

This started later, the beginnings, the 1960s, were when villages developed greatly. This was home-made brick, and there Widełka and Przewrotne, they were being built up. He could not afford brick at a brick plant and it was difficult to buy it. $[\ldots]$ There were many masons and they could not keep up. ${ }^{55}$

(Przewrotne, Niżatyce).$^{56}$

However, key changes in architecture took place after the political transformation of the 1990 s and in the first years of the twenty-first century (Lapajówka), ${ }^{57}$ when the traditional way of life of the inhabitants of villages changed almost overnight.

\section{Traditional wooden architecture of the Rzeszowiacy—an overview Village types}

The areas of the central basin of the River Wisłok turned out to be an attractive place for settlers. A dense network of towns and villages had developed here already by the Middle Ages. The stabilised geopolitical situations of the inhabitants and the pre-determined settlement network caused these areas to be "ignored" during the nineteenth-century Josephine

\footnotetext{
51 These villages were thoroughly studied in the years 1979-1982 by employees of the Rzeszów Ethnographic Museum and the material collected at the time was documented and published in the fifth volume of "Prace i Materiały z Badań Etnograficznych", Rzeszów, 1985.

${ }^{52}$ DRAGAN, Budownictwo drewniane..., p. 237.

${ }^{53}$ Ibid.

${ }^{54}$ Jawornik Polski, JC, MKL-AE 617/3; Wólka Podleśna, LM, MKL-AE 557/4; Zabajka, FA, MKL-AE 556/11.

${ }^{55}$ DRAGAN, Budownictwo drewniane..., p. 238.

${ }^{56}$ Przewrotne, SF SW, MKL-AE 558/5; Niżatyce, Z-KL, MKL-AE 611/3.

${ }^{57}$ One informant reported that current travels are mostly focused on guest employment, with many migrants investing their earnings in building themselves a house (Lapajówka, DH, MKL-AE 620/1).
} 
T. Tomaszek.: The Role of the Kolbuszowa Folk Culture Open-Air Museum in Studies...

colonisation, which at the time exerted a considerable impact on rural development in the less-populated nearby areas. ${ }^{58}$ The effects of being omitted from this immense and organised settlement campaign, which introduced significant change to the culture landscape, were the rather slow changes shown by the Rzeszowiacy, changes that were based on long-lasting cultural continuity instead of sudden settlement-type modifications. ${ }^{59}$

Two types of village layouts were the most common among the Rzeszowiacy: niwa-type and łan-and-chain-type villages. As noted by Dragan, ${ }^{60}$ the types of rural development were divided by the River Wisłok, its central run to be precise, as niwa-type villages predominated to the north of it, and łan-type predominated to its south. It should be highlighted that niwa-type villages were original, while the founding of łan-type villages started to appear after foundings based on German town laws had been introduced. ${ }^{61}$ The southernmost areas, located in the foothills, largely featured hamlet-type villages. ${ }^{62}$ The farmers who settled in mountainous areas built their farms in forest meadows or clearings, sited far apart from each other due to the terrain.

\section{Farm types}

The area under analysis was dominated by a farm type composed of multiple buildings (multiple-building farms). However, the number and placement of buildings, and thus the size of the farm itself, depended on the owner's wealth. Farms distinctive to averagely wealthy households were the most common and were usually composed of two buildings: a cottage and a stable under one roof, and a barn, which was typically placed parallel to the cottage. ${ }^{63}$ If the terrain allowed it, such farms also featured a cellar, typically located near the cottage. ${ }^{64}$ The most impressive farms, unsurprisingly, belonged to well-to-do peasants, who were called "kmiecie". Customarily, such farms consisted of a cottage, one or sometimes two barns, a stable, a cellar, and a wagon shed. ${ }^{65}$ They also often featured separate pig and chicken pens, and in the case of a need to store considerable amounts of hay or straw-hay barracks. ${ }^{66}$ Meanwhile, the poorest residents of a village owned single-building farms, where the cottage and animal pens were all under one roof and the attic typically acted as a barn. ${ }^{67}$

As observed by Dragan, ${ }^{68}$ farms were built on relatively narrow, long plots. The cottages were built from the side of the main road and faced it with their gables, the outbuildings were behind them, while on the back of the plot, with their fronts facing the fields or the threshing road, the barns were located. "The cottages typically stood with their narrow side facing the road,

\footnotetext{
${ }^{58}$ DRAGAN, Budownictwo drewniane..., p. 241.

${ }^{59}$ LEPUCKI, Henryk. Działalność kolonizacyjna Marii Teresy i Józefa II w Galicji 1772-1790. In: Franciszek Bujak (ed.). Badania z Dziejów Społecznych i Gospodarczych, nr 29. Wydano z Zasiłku Zwrotnego Ministerstwa Wyznań Religijnych i Oświecenia Publicznego. Lwów, 1938.

${ }^{60}$ DRAGAN, Budownictwo drewniane..., p. 241.

${ }^{61}$ RUSZEL, Z badań nad kultura..., p. 15.; STYŚ, Wincenty, Drogi postępu gospodarczego wsi. Studium szczegótowe na praykeładzie zbiorowości próbnej wsi Husów. Wrocław: Wrocławskie Towarzystwo Naukowe, 1947; RUSZEL, Krzysztof. Leksykon kultury ludowej w Rz̨eszowskiem. Rzeszów: Muzeum Okręgowe Oddział Rzeszów, 2004, p. 454.

${ }^{62}$ KARCZMARZEWSKI, Andrzej. Budownictwo ludowe okolic Rzeszowa. In: Krzysztof Ruszel (ed.). Prace $i$ Materialy z Badań Etnograficznych Vol. 5. Rzeszów: Muzeum Okręgowe w Rzeszowie, 1985, p. 58.

${ }^{63}$ DRAGAN, Budownictwo drewniane..., p. 242.

${ }^{64}$ KARCZMARZEWSKI, Rzeszowiacy..., p. 13.; Nowa Wieś, PT, MKL-AE 554/7

${ }^{65}$ KARCZMARZEWSKI, Budownictwo..., p. 57.; Krzemienica, BJ BJ, MKL-AE-647/1.

${ }^{66}$ RUSZEL, Leksykon kultury..., p. 454.

${ }^{67}$ KARCZMARZEWSKI, Budownictwo..., p. 58.

${ }^{68}$ DRAGAN, Budownictwo drewniane..., p. 242.
} 
although my neighbour had it the other way around. The barn was behind it, perpendicular. The farm also had a well, which was sometimes shared with a neighbour." (Nowa Wieś) ${ }^{69}$

Based on many years of field work conducted by the Kolbuszowa Folk Culture Museum, it was possible to note significant differences between each subregion inhabited by the Rzeszowiacy in terms of farm layout and type..$^{70}$ And so, in Rzeszowskie, the most common farms were of the multiple-building type, where buildings were placed at considerable distances from each other. ${ }^{71}$ In Lańcuckie, and also partially in Przeworskie, a type of farms with a socalled ring (or market) ${ }^{72}$ became popular. Their plan was based on siting the cottage and stable parallel to each other, while the space between them was enclosed (partitioned off) with a fence and a wicket. ${ }^{73}$ In some farms, the third side was enclosed by pigsty. The interior of the farm (the ring) was used to store manure prior to carting it off into the fields. The remaining buildings - the barn, the granary, wagon shed, and others - were outside the ring. This was also often associated with raising production levels and the need to store the harvest, which would be impossible in a small, internally closed farm. ${ }^{74}$

Apart from the abovementioned farm types, the areas inhabited by the Rzeszowiacy also featured another type of farm, found mainly in the village of Markowa. It is a distinctive form of enclosed farm, called the "obora", and which shows traces of Wallachian" ${ }^{75}$ architectural tradition while also displaying similarity to Lemko or Hutsul pastoral settlements. ${ }^{76}$

\section{Building types and structural systems}

Similarly to many villages in other areas of Poland, the primary building material used in the land around Rzeszów up to the middle of the twentieth century was wood. It was used to build both houses and all other farm buildings. ${ }^{77}$ This is confirmed by the literature and previous

\footnotetext{
${ }^{69}$ Nowa Wieś, PS, MKL-AE 562/3.

${ }^{70}$ DRAGAN, Budownictwo drewniane..., p. 243.

${ }^{71}$ KARCZMARZEWSKI, Budownictwo..., p. 58. ; KARCZMARZEWSKI, Rzeszowiacy..., p. 12.

${ }^{72}$ KOTULA, Franciszek. Typy wiejskich drewnianych budynków na podgórzu w województwie rzeszowskim. In: Ochrona Zabytków, 11, 1-2 (40-41), 1958, p. 55.; TEJCHMA, Dawniej..., p. 25.; TŁOCZEK, Ignacy. Chatupy polskie. Warszawa: Arkady, 1958, p. 14.

${ }^{73}$ DRAGAN, Budownictwo drewniane..., p. 243.

${ }^{74}$ E.g. the plan of a farm from Markowa (Szylary) at the Open-Air Folk Museum in Kolbuszowa, or the plan of a well-to-do peasant's farm at the Markowa Village Museum in Markowa.

${ }^{75}$ DRAGAN, Budownictwo drewniane..., p. 243.

${ }^{76}$ The literature ascribes a significant impact on the formation of these Carpathian highlander groups to Wallachians: BLIN-OLBERT, Danuta. Budownictwo u Lemków. In: Krzysztof Staszewski (ed.). Dawna architektura drewniana województwa podkarpackiego. Rzeszów: Stowarzyszenie Pro Carpathia, 2016, p. 54; TEJCHMA, Dawniej..., p. 25.

${ }^{77}$ Gać, ZS, MKL-AE 614/4; Gać, ZS, MKL-AE 614/3; Grzęska, MS, MKL-AE 618/4; Lapajówka, DH, MKL-AE 620/1; Borek Stary, NN, MKL-AE 652/1; Łąka, KJ, MKL-AE 554/3; Łukawiec, KB, MKL-AE 554/5; Niżatyce, PE, MKL-AE 611/ l; Niżatyce, PJ, MKL-AE 611/2; Niżatyce, Z-KL, MKL-AE 611/3; Trzebownisko, NN, MKL-AE 562/1; Nowa Wieś, MA, MKL-AE 554/6; Nowa Wieś, PT, MKL-AE 554/7; Przewrotne, BA, MKL-AE 562/5; Przewrotne, DA, MKL-AE 562/6; Chmielnik, MJ, MKL-AE 652/4; Łańcut, TA, MKL-AE 649/5; Sonina, DE, MKL-AE 652/6; Wysoka, MH, MKL-AE 646/7; Dębów, NN, MKL-AE 619/ 1; Gać, PJ, MKL-AE 614/1; Gać, ZJ, MKL-AE 614/2; Handzlówka, PA, MKL-AE 648/3; Borek Stary, NN, MKL-AE 652/3; Jawornik Polski, CJ JJ, MKL-AE 617/3; Handzlówka, PK, MKL-AE 650/8; Gorliczyna, ŻZ, MKL-AE 618/2; Nowa Wieś, PS, MKL-AE 562/3; Nowa Wieś, SA, MKL-AE 559/1; Siennów, SS, MKL-AE 612/7; Wólka Podleśna, LM, MKL -AE 557/4;Wólka Podleśna, RJ, MKL-AE 562/8; Wólka Podleśna, WM, MKL-AE 557/6; Zabajka, FA, MKL-AE 556/11; Zabajka, PG, MKL-AE 556/13; Zabajka, PA, MKL-AE 556/14; Żuklin, FS, MKL-AE 611111. (Archival documents from the archives of the Folk Culture Open-Air Museum in Kolbuszowa and after: DRAGAN, Budownictwo drewniane..., pp. 243-245).
} 
studies and earlier reconnaissance. ${ }^{78}$ Pine and fir wood was used the most often (Medynia Głogowska, Przewrotne, Wółka Podleśna), ${ }^{79}$ while the wood of deciduous trees was used much more rarely, effectively only to make structural details (Nowosielce). ${ }^{80}$ As noted by Dragan, ${ }^{81}$ the material was procured either in one's own forest or purchased from a local landowner or his tenants, ${ }^{82}$ or alternatively from a Jewish merchant (Nowosielce, Chmielnik). ${ }^{83}$ Timber was properly procured from trees cut "up to the juices", namely only in winter, when a tree starts "to produce juices" (Medynia Głogowska). ${ }^{84}$

The findings of field studies performed by the Kolbuszowa Folk Culture Museum indicate that since the 1920s, wealthier peasants from the Rzeszów area began owning the first masonry or mixed-structure timber and masonry houses (Nowa Wieś, Gać, Wólka Podleśna, Husów). ${ }^{85}$ The new material, brick, was fired at local brickmaking plants (Wysoka, Gać). ${ }^{86}$ According to Dragan, ${ }^{87}$ there were sporadic instances of houses built out of rammed earth mixed with chopped plant matter (Chmielnik) during this period. ${ }^{88}$ This technology, arising from a lack of other building materials, allowed for the effective reconstruction of a portion of buildings that burned down during the Second World War.

According to field study findings, the Rzeszowiacy sited their initially wooden buildings directly on stones or oak stubs - so-called sheafs_-and later, since around the middle of the nineteenth century, also on brick foundations (Wólka Podleśna). ${ }^{89}$ The manner of building the structure of the walls of the buildings differed between subregions. ${ }^{90}$ In Rzeszowskie, the log structure was the most common (Siennów), ${ }^{91}$ while the oldest buildings had saddlenotch (na obłap) corners, while through dovetail joints with end projections (called kaniuchy) became more common in a later period ${ }^{92}$ (Wólka Podleśna). ${ }^{93}$ In the final stage of this building tradition, the corners were smoothed, with the end projections sawn off (Wólka Podleśna), ${ }^{94}$ making the corners flush with the walls. As highlighted by Dragan, ${ }^{95}$ such log walls were later often covered with wooden siding (Lapajówka, Lukawiec). ${ }^{96}$ In Lańcuckie and Przeworskie, the buildings were commonly erected with combination log- and timber-framing (Umgebindehäuser, also called Upper Lusatian houses), or timber-framing structural systems, which are characterised by

\footnotetext{
${ }^{78}$ KARCZMARZEWSKI, Budownictwo..., p. 64.

${ }^{79}$ Medynia Głogowska, PM, MKL-AE 646/3; Przewrotne, BA, MKL-AE 562/5; Wólka Podleśna, LM, MKL-AE $557 / 4$.

${ }^{80}$ Nowosielce, DS, MKL-AE 619/4.

${ }^{81}$ DRAGAN, Budownictwo drewniane..., p. 244.

${ }^{82}$ Medynia Głogowska, PM, MKL-AE 646/3.

${ }^{83}$ Nowosielce, DS, MKL-AE 619/4; Chmielnik, NH, MKL-AE 648/1.

${ }^{84}$ Medynia Głogowska, PM, MKL-AE 646/3.

${ }^{85}$ Nowa Wieś, PS, MKL-AE 562/3; Gać, ZS, MKL-AE 614/4; Wólka Podleśna, LM, MKL-AE 557/3; Husów, LK, MKL-AE 653/2.

${ }^{86}$ Wysoka, BJ ZL HL, MKL-AE 646/8; Gać, ZS, MKL-AE 614/4.

${ }^{87}$ DRAGAN, Budownictwo drewniane..., p. 244.

${ }^{88}$ Chmielnik, PZ, MKL-AE 648/2.

${ }^{89}$ Wólka Podleśna, WM, MKL-AE 557/6.

${ }^{90}$ DRAGAN, Budownictwo drewniane..., p. 245.

${ }^{91}$ Siennów, SS, MKL-AE 612/7; Siennów, SS GJ, MKL-AE 612/7.

${ }^{92}$ DRAGAN, Budownictwo drewniane..., p. 245.

${ }^{93}$ Wólka Podleśna, WM, MKL-AE 557/6.

${ }^{94}$ Wólka Podleśna, LM, MKL-AE 557/4.

${ }^{95}$ DRAGAN, Budownictwo drewniane..., p. 245.

${ }^{96}$ Lapajówka, DH, MKL-AE 620/1; Lukawiec, KB, MKL-AE 554/5.
} 
the roof's load-bearing structure being supported by external columns (Siennów, Chmielnik, Gać) ${ }^{97}$ According to Dragan, ${ }^{98}$ this is the most characteristic feature of the area's architecture, which defines its distinctiveness.

The specificity of the Umgebindehaus-type structure is that notched log walls are built for the residential and farming sections separately (as if they were two independent buildings), while both are covered with a roof that rests on an independent timber frame, based on columns standing outside of the walls. The columns are connected by doubled purlins (beams), placed longitudinally and transversely, that act as supports for rafters. The beams are bound with the columns via scissor braces (pietnary). All of the elements of the column structure are joined using oaken dowels. ${ }^{99}$ The Umgebindenhaus-type structural system, highly original and architecturally attractive, was not found in any of the adjacent regions. The skill to erect such buildings was most probably brought to the area along with German settlers, who came to the area from Saxony at the behest of Casimir the Great in the fifteenth century. ${ }^{100}$ As noted by F. Kotula, in the 1940s and in the beginning of the 1950s this architecture was exclusively replaced by log buildings, while older column-based buildings were either dismantled or remodelled. ${ }^{101}$

Citing K. Moszyński, aside from association with a specific region, the manner of erecting the buildings was also affected by ethnic elements. Moszyński argued that among residents of Polish origin, the log cabin structure predominated, while among those of Ruthenian origin, the significance of the log cabin structure was similar to that of a post-and-plank structure. ${ }^{102}$

Dragan reported that roof trusses were built in the same manner in every subregion, mostly as rafter-based or rafter-and-collar-beam trusses. In Rzeszowskie, they were placed on the uppermost beams of the wall, the wall plates (called platwie), while in Przeworskie and Łańcuckie they were supported by structural columns. The roofs were mostly rafter-and-collarbeam trusses, and were built either as hipped or gable roofs and covered with thatch placed either in a stepped fashion or flatly ${ }^{103}$ (Przewrotne, Siennów, Krzeczowice, Niżatyce, Nowa Wieś, Sonina, Gać, Dębów, Wysoka, Siennów, Kosina). ${ }^{104}$

\footnotetext{
${ }^{97}$ PODGÓRSKI, Antoni Maria. Dwa sqųzególne żnamiona budownictwa w Rz̧eszowskiem. Rzeszów, 1857, p. 11; KOTULA, Franciszek. Słupowe chałupy w Rzeszowskiem. In: Ochrona Zabytków, 6/ (23), 1953, pp. 213-215.; KOTULA, Typy wiejskich..., pp. 40-42.; Siennów, SS GJ, MKL-AE 612/7; Chmielnik MJ, MKL-AE 652/4; Gać, ZS, MKL-AE 614/3; Gać, PJ, MKL-AE 614/ 1; Gać, ZJ, MKL-AE 614/2.

${ }^{98}$ DRAGAN, Budownictwo drewniane..., p. 245.

99 TEJCHMA, Dawniej..., p. 49.

${ }^{100}$ KOTULA, Słupowe..., p. 216.

${ }^{101}$ Ibid., p. 211.

${ }^{102}$ MOSZYŃSKI, Kazimierz. Kultura ludowa Stowian. Part I: Kultura Materialna. Warszawa: Wydawnictwo Graf_ika, 2018 , p. 510.

${ }^{103}$ DRAGAN, Budownictwo drewniane..., p. 246.

${ }^{104}$ Przewrotne, DA, MKL-AE 562/6; Przewrotne, BA, MKL-AE 562/5; Siennów, SS, MKL-AE 612/7; Krzeczowice, BA, MKL-AE 612/2: the informant stated that the type of bundle used in thatching mattered, as the sheaf bundle required a greater amount of thatching material than the flat bundle; Niżatyce, PJ, MKL-AE 611/2; Niżatyce, Z-KL, MKL-AE 611/3; Nowa Wieś, PT, MKL-AE 554/7; Sonina, RE, MKL-AE 648/5; Gać, ZS, MKL-AE 614/4; Nowa Wieś, PS, MKL-AE 562/3; Dębów, NN, MKL-AE 619/ 1; Wysoka, MH, MKL-AE 646/7; “'The roofs were covered with sheaf bundles of rye straw": Siennów, SS, MKL-AE 612/7; “[...] before that there were straw bundles, flat ones for thatching": Kosina, TT, MKL-AE 651/6; Kosina, UM, MKL-AE 651/7. (Field notes from the collections of the Folk Culture Open-Air Museum in Kolbuszowa and after: DRAGAN, Budownictwo drewniane..., pp. 246-247).
} 
T. Tomaszek.: The Role of the Kolbuszowa Folk Culture Open-Air Museum in Studies...

Fireproof cement (Nowa Wieś, Łapajówka, Nienadówka, Kosina) ${ }^{105}$ or ceramic (Przewrotne, Łańcut, Nowa Wieś, Białobrzegi, Lapajówka, Kosina) ${ }^{106}$ roof tiles had already begun to replace thatching prior to the Second World War. As highlighted by Dragan, who cited field studies as his source, ${ }^{107}$ tiles were often first used as roofing for outbuildings, mostly stables, while houses were covered later. "The house was covered with thatch. But the outbuilding was roofed with tiles" (Nowa Wieś). ${ }^{108}$

The Rzeszowiacy often painted the exteriors of their cottages, yet over time unpainted cottages began to predominate. ${ }^{109}$ The main method of "painting" was based on whitewashing the cottages with lime with an admixture of paint called siwka (Nowa Wieś Zaczerska). ${ }^{110}$ Initially, only the strips of clay used to caulk the gaps between logs were painted, ${ }^{111}$ but over time the strips around doors and windows began to be painted as well, forming wide, white surrounds, ${ }^{112}$ and ultimately entire walls were washed with lime (Gać, Wysoka). ${ }^{113}$ According to Dragan, ${ }^{114}$ it was mainly the housing sections of cottages that were whitewashed, with the farming sections left without a finish. The decoration (whitewashing) itself often had customary significance, as it was a sign that the house was inhabited by a girl available for marriage (Laka). ${ }^{115}$

It should be noted that the farming buildings built in peasants' farms (mostly those owned by well-to-do farmers) of the Rzeszowiacy included treadmill wagon sheds and a special type of barn-maneże (manège). Both of these architectural types were either very rare or nonexistent in adjacent areas. ${ }^{116}$ The wagon sheds were used to store horse-drawn wagons and agricultural equipment, while the maneże were large, sometimes even monumental single-space buildings used to house treadmills that allowed people and horses to work regardless of weather. Periodically, they could also have been used as sheds to store wagons, sleds, or agricultural tools and machinery. ${ }^{117}$

\footnotetext{
105 "And when my brother grew up, we already had the casts for making roof tiles, so we roofed the entire house": Nowa Wieś, PT, MKL-AE 554/7; Lapajówka, DH, MKL-AE 620/1; Nienadówka, MP, MKL-AE 646/3. "The roof tiles were made in Terliczka and Jasionka, and before that there was a roof tile workshop in Zaczernie. Henryk Bieniek, who lives in the last house before Zaczernie, ran a roof tile workshop in Nowa Wieś": Nowa Wieś, PS, MKLAE 562/3; “[...] later it was done with cement roof tiles made on-site-one fellow in Kosino had a metal form, he rammed them, smoothed them and dried them": Kosina, TT, MKL-AE 651/6. (Field notes from the collections of the Folk Culture Open-Air Museum in Kolbuszowa).

106 Przewrotne, BA, MKL-AE 562/5; Łańcut, TA, MKL-AE 649/5; Gać, ZS, MKL-AE 614/4; Nowa Wieś, PS, MKL-AE 562/3; the informants had a house covered with roof tiles from a tile workshop in Korinaktów Południowy that had operated before the First World War and had been owned by the Lubomirski family: Lańcut, ŚJ ŚL, MKL-AE 649/7; Łapajówka, DH, MKL-AE 620/1; “[...] red roof tiles were being fired in Rzeszów”: Kosina, UM, MKL-AE 651/7; “[...] later the ceramic tiles were from Dobrzechów”: Kosina, TT, MKL-AE 651/6. (Field notes from the collections of the Folk Culture Open-Air Museum in Kolbuszowa).

${ }^{107}$ DRAGAN, Budownictwo drewniane..., p. 247.

${ }^{108}$ Nowa Wieś, PT, MKL-AE 554/7.

${ }^{109}$ DRAGAN, Budownictwo drewniane..., p. 248.

${ }^{110}$ Nowa Wieś, SA, MKL-AE 559/1.

111 TEJCHMA, Dawniej..., pp. 43, 45, 48.

${ }^{112}$ DRAGAN, Budownictwo drewniane..., p. 247.

${ }^{113}$ Gać, ZS, MKL-AE 614/4; Wysoka, MH, MKL-AE 64617.

${ }^{114}$ DRAGAN, Budownictwo drewniane..., p. 247.

${ }^{115}$ A trace of this custom has survived in a ritual wedding song that was sung on the way to church: "The house of my girl, the house of my beloved, has painted windows, and painted walls": Laka, KJ, MKL-AE 554/3.

${ }^{116}$ DRAGAN, Budownictwo drewniane..., p. 249.

117 TEJCHMA, Dawniej..., p. 33.
} 
Among other interesting farming building types one can also note granaries (solki) built outside of the general area of the farm, which were used to store grain seeds. Where the terrain allowed, granaries were built atop masonry cellars built out of brick or stones ${ }^{118}$ (Nowa Wieś). ${ }^{119}$

The interior plans of the cottages built by the Rzeszowiacy were closely tied with the wealth of the cottage's owners. ${ }^{120}$ The most complicated two-bay layout that offered the greatest arrangement potential was present in farms of well-to-do peasants. The farms of those of average wealth usually featured one-and-a-half-bay layouts, while those of the poorest had single-bay layouts. The latter layout was also present in small cottages built as a part of the farms of well-to-do peasants. These buildings were used by farmhands who worked on the farm of the wealthier owner.

A typical cottage built by the Rzeszowiacy was divided into a housing section and an ancillary section, which were separated from each other by a pass-through hallway. There were cases of single-space housing sections, but they were typically comprised of two spaces ${ }^{121}$ - a larger space called izba (chamber) or kuchnia (kitchen), which housed a large furnace, and a second, smaller one, called either an alkierz (bedroom) or pokój (room) (Lapajówka, Krzemienica). ${ }^{122}$ Single-chamber cottages often had partitioned hallways, with the resulting space used as a kitchen. The ancillary section typically consisted of a storage space called the komora. Older or poorer cottages often had the ancillary section divided into two spaces, one for storage and another for a stable. ${ }^{123}$ There were also sporadic cases where a house and an outbuilding were built under one roof. ${ }^{124}$

\footnotetext{
${ }^{118}$ DRAGAN, Budownictwo drewniane..., p. 249.

${ }^{119}$ Nowa Wieś, MA, MKL-AE 554/6.

${ }^{120}$ TŁOCZEK, Chałupy..., p. 14.; KARCZMARZEWSKI, Rzeszowiacy..., p. 13.

${ }^{121}$ Borek Stary, NN, MKL-AE 652/ I; Zabajka, PA, MKL-AE 556/14; Zabajka, PG, MKL-AE 556/13; Wólka Podleśna, RJ, MKL-AE 562/8; Przewrotne, BA, MKL-AE 562/5; Przewrotne, DA, MKL-AE 562/6; Lukawiec, KB, MKL-AE 554/5; Nowa Wieś, MA, MKL-AE 554/6.

${ }^{122}$ Łapajówka, DH, MKL-AE 62011; “[...] one half of the house comprised two rooms. The second house was the kumora (chamber). Between them was a hallway, which could not be passed through, with a small kitchen sectioned off from it. In the kitchen-room there stood a furnace, which passed into the second room, and a bread furnace": Krzemienica, JB, MKL-AE 647/1. (After DRAGAN, Budownictwo drewniane..., p. 249).

${ }^{123}$ One informant said: "We had typical Galician poverty here. Most families had many children. Most houses were wooden, with one living space. We had hard earthen floors. A child in every corner and four on the furnace. There were houses where there was one living space and on the other side of the hallway there was a barn with a cow. In the poorest houses the cows were taken into the living spaces so they would not freeze" (Jawornik Polski, JC, MKL-AE 617/3), while another stated: "there was one room, inside were two beds, and a kitchen this big, out of brick. [...] But it wasn't just us, many slept like that. On the floor of the cottage there was clay, there was the kumora, where we had some grain. The same building had a stable, we got into it through the hallway. Through this hallway cows entered one room and we entered another. All this was in a single cottage, only the doors to the stable were closed" (Nowa Wieś, MA, MKL-AE 554/6) (after DRAGAN, Budownictwo drewniane..., p. 250).

${ }^{124}$ One informer argued: "The house is connected with a farm building. They were built so because one wall was free, from both sides. Between the house and the farm buildings — the shed and barn — was a threshing floor, where you left the wagon, the cart stands there" (Kosina, UM, MKL-AE 651/7), while another reported: "In the past the house was lived in by both people and animals. You will not find any of this now, but when you went left you enter the room for animals while the family lived to the right. You went into a hallway, on one side was the komora, one half of it was usually for a horse, and on the other side there was one room" (Nowa Wies, PS, MKL-AE $562 / 3$ ) (Field notes from the collections of the Folk Culture Open-Air Museum in Kolbuszowa, and after DRAGAN, Budownictwo drewniane..., p. 251).
} 


\section{Architectural structures in the cultural landscape of the Rzeszowiacy}

Other elements that were distinctive of the cultural landscape of the Rzeszowiacy included wooden structures erected by wealthy landowners, such as palaces, manors or grange buildings. Unfortunately, information about these types of buildings collected during field studies is very limited. ${ }^{125}$ The reason for this is the fact that most such buildings had already been destroyed during the first half of the twentieth century.

Undoubtedly, the most impressive timber buildings in the area inhabited by the Rzeszowiacy were the structures that formed church and parish complexes, which, similarly to the estates of landowners, stood out not only through their monumental architecture, but also the size of the sites they occupied. Here it should be mentioned that late-Gothic wooden churches had been slowly replaced by masonry ones, which towered above their surroundings even more, since the middle of the nineteenth century. Despite this tendency, the land inhabited by the Rzeszowiacy still sports numerous historical wooden churches (e.g. in Krzemienica, Nowosielce, Handzlówka, Zaczernie or Siedleczka). ${ }^{126}$

Among other building types commonly encountered in the area, just as in other parts of Poland, there are inns, taverns, and all sorts of public buildings like fire-stations, community houses, parish houses (Przewrotne, Chmielnik, Gać, Gorliczyna, Głogów Małopolski, Hyżne, Siedleczka, Urzejowice), ${ }^{127}$ as well as buildings associated with crafts and rural industries, such as: smithies, oil making workshops, grain mills, and windmills (Białobrzegi, Chmielnik, Krzemienica, Pogwizdów, Łańcut, Sonina, Wola Mała, Gać, Kosina, Niżatyce, Łąka, Nowa Wieś Zaczerska, Jasionka). ${ }^{128}$ As noted by Dragan, the last of these types of architectural structures (rural industry and crafts buildings) did not differ significantly from those erected in other areas of Poland, as their structural systems were defined primarily by ages-old functional principles. $^{129}$

Shrines and roadside crosses with wooden depictions of saints that enjoyed particular recognition in the area complemented the landscape of every village of Rzeszowiacy. Since the beginning of the twentieth century, the place of wooden shrines was slowly being taken by masonry ones, often with a new form, e.g. that of a small house, a lantern, a tower or column ${ }^{130}$ (Sonina, Nowa Wieś, Lipnik, Łapajówka, Przeworsk-Gorliczyna, Tajęcina, Krzeczowice). ${ }^{131}$

\footnotetext{
${ }^{125}$ DRAGAN, Budownictwo drewniane..., p. 254.

${ }^{126}$ Ibid.

${ }^{127}$ Przewrotne, DA, MKL-AE 562/6; Chmielnik, MJ, MKL-AE 652/4; Gać, ZS, MKL-AE 614/4; Gać, ZS, MKL-AE 614/3; Gorliczyna, ZZ, MKL-AE 618/2; Głogów Młp., ŁW, MKL-AE 556/2; Hyżne, OA, MKL-AE 653/5; Siedleczka, GH, MKL-AE 613/2; Siedleczka, WJ, MKL-AE 613/6; Urzejowice, KR, MKL-AE 620/4.

${ }^{128}$ Białobrzegi, HZ, MKL-AE 649/ 1; Chmielnik, NH, MKL-AE 648/ 1; Krzemienica, BP BZ, MKL-AE 647/2; Białobrzegi, ŚJ, MKL-AE 649/4; Pogwizdów, BJ, MKL-AE 646/4; Lańcut, TA, MKL-AE 649/5; Sonina, RE, MKL -AE 648/ 5; Lańcut, ŚJ ŚL,MKL-AE 647/7; Wola Mała, SR, MKL-AE 647/7; Gać, PJ,MKL-AE 614/ 1; Kosina, TT, MKL-AE 651/6; Niżatyce, PE, MKL-AE 611/1; Łąa, KJ, MKL-AE 554/3, Nowa Wieś, SA, MKL-AE 559/ 1; Chmielnik, PZ, MKL-AE 648/2; Białobrzegi, ŚJ, MKL-AE 649/4;Łańcut, Ś ŚL,MKL-AE 647/7; Jasionka, SB, MKL-AE 562/7. (Field notes from the collections of the Folk Culture Open-Air Museum in Kolbuszowa, and after DRAGAN, Budownictwo drewniane..., pp. 249-253).

${ }^{129}$ DRAGAN, Budownictwo drewniane..., p. 256.

${ }^{130}$ Ibid., p. 257.

${ }^{131}$ Sonina, MA, MKL-AE 648/4; Nowa Wieś, PS, MKL-AE 562/3; Lipnik, KD, MKL-AE 615/1; Lapajówka, WH, MKL-AE 620/2; Gorliczyna, ST, MKL-AE 618/1; Tajęcina, KW KB, MKL-AE 559/3; Krzeczowice, BA, MKL-AE 612/2.
} 
Traditional wooden folk architecture of the Rzeszowiacy in the collection of the Kolbuszowa Open-Air Folk Culture Museum

The Kolbuszowa Open-Air Folk Culture Museum presents the material culture of the Lasowiacy and Rzeszowiacy ethnographic groups, which used to inhabit the northern parts of the present-day Podkarpackie Voivodeship. Over eighty large and small specimens of wooden architecture are exhibited on an almost 30 ha site. These specimens include cottages, animal

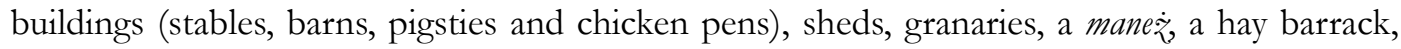
rural industry buildings such as a watermill, several windmills, smithies, oil making and potter's workshops, as well as public buildings — a school, an inn, a tavern, and a fire station, in addition to the impressive Church of St Mark the Evangelist. The oldest buildings include, among others, a manor from Brzeziny from 1753, a manorial granary from Bidziny from 1784, a cottage from Markowa from 1804, and a church from Mielec-Rzochów built in 1843.

The buildings have been presented in their natural relationships and in an environment similar to the one that used to accompany them. The individual buildings are paired into farms following the layout of the settlement in which were originally built, while the farms repeat the spatial layouts of traditional rural developments of the Lasowiacy and Rzeszowiacy from the turn of the twentieth century. The buildings are sited in the natural landscape of house gardens, orchards, bee farms and fields, meadows, pastures, and ponds. The area is surrounded by a forest that brings to mind past thickets and the Sandomierz Forest that used to cover the area.

The sector of the Open-Air Museum dedicated to the architecture of the Rzeszowiacy presents the following buildings:

-A manor from Sędziszów Małopolski from the middle of the nineteenth century-a specimen of a building that references a noble manor; given to the open-air museum by the Municipality of Sędziszów Małopolski in 1992 (building no. 3 on the museum map)

-A house from Żołynia from 1815-an example of a residential building typical of the small towns around Rzeszów (building no. 5 on the museum map)

—A watermill from Żołynia Dolna near Lańcut from 1897 (building no. 40 on the museum map)

-A farm from Budziwoj (no. 37 on the museum map). The farm includes:

- A cottage from Budziwoj (1867), a specimen of a monumental cottage of a well-to-do peasant,

- A barn from Budziwoj (middle of the nineteenth century),

- A cellar from Budziwoj (a reconstruction from 1986),

- A granary from Ropczyce (turn of the nineteenth century).

-A farm from Markowa (Kielarów), which has a building layout distinctive of villages from around Rzeszów. The cottage, stables and pigsties form a closed rectangle. The entrance to the enclosure has the form of a wicket in a high fence made from wooden boards. Behind is a rectangular square with a deep manure pit in the centre. This square was called a "obora" (no. 35 on the museum map). The farm includes:

- A cottage from Markowa (1804) — the oldest cottage in the museum,

- A stable from Markowa (the end of the nineteenth century),

- A well with a crane.

—A post mill from Markowa from 1935 (building no. 52 on the museum map)

- A farm from Markowa (Szylarów) which is a very good example of the distinctive manner of building in the village of Markowa, where the Umgebindenhaus-type structural system was 
T. Tomaszek.: The Role of the Kolbuszowa Folk Culture Open-Air Museum in Studies...

used - the walls were erected using a log structure and were independent of the roof, while the roof truss was supported by massive columns that stood beside the walls and did not exert any load on them (building no. 33 on the museum map). The farm includes:

- A cottage from Markowa (turn of the nineteenth century),

- A stable from Markowa (beginning of the twentieth century),

- A shed from Markowa (nineteenth century),

- A granary from Markowa (nineteenth century),

- A treadmill maneż (reconstruction of a building from the nineteenth century).

-A fire-station from Słociny from 1877 (building no. 34 on the museum map)

-A shrine from Rakszawa from the end of the nineteenth century - a house-type shrine (no. 69 on the museum map)

-A farm from Brzóza Stadnicka (no. 32 on the museum map). The farm includes:

- A cottage from Brzóza Stadnicka (second half of the nineteenth century),

- A farm building from Brzóza Stadnicka (second half of the nineteenth century),

- A shed from Rzeszów (second half of the nineteenth century)

- An oilmaking workshop from Brzyska Wola (turn of the nineteenth century).

-An inn and tavern from Hadle Kańczuckie from the end of the nineteenth century (building no. 24 on the museum map)

-A smithy from Białobrzegi from 1881 (building no. 51 on the museum map).

\section{Final remarks}

Since its establishment, the Kolbuszowa Open-Air Folk Culture Museum has performed far-reaching actions in terms of academically documenting the rapidly disappearing traditional wooden architecture of the central and northern part of the Podkarpackie Voivodeship-the area inhabited by the Lasowiacy and Rzeszowiacy ethnographic groups. At the same time, as a museum institution, it has contributed to saving numerous valuable buildings that have been relocated to the Ethnographic Park. Thanks to this initiative, it was possible to preserve the architectural heritage of these lands, which, in a period of globalisation and drastic social changes observed on the cusp of the third millennium, are a testament to the wealth of material culture of south-eastern Poland.

The Rzeszowiacy ethnographic group to which this paper is devoted occupies a special place on the map of the Podkarpackie Voivodeship. These people inhabit areas with an extraordinarily complicated and interesting history, marked by the influence of both settlers from the east and of German origin. The architectural traditions and structural solutions developed in these areas have no equal and are considered highly unique. These include the previously mentioned method of erecting buildings in the Umgebindehaus-type structure, which the village of Markowa is especially famous for. This method was created as a result of the mixing of influences and traditions from different parts of Europe, resulting in a system that is specific solely to this region.

The academic research conducted by the Kolbuszowa Open-Air Folk Culture Museum has become a basis for a more comprehensive outlook on the essence of the cultural heritage of the individual ethnographic groups that inhabit the territory of Poland. It is in these small achievements of individual communities that the holistic image of national culture lies, along with its spiritual and material specificity. Recognising these small contributions and their 
significance in the shaping of a complete image of national tradition has thus become a turning point in Polish museology.

Of course, the actions taken by the Kolbuszowa Open-Air Folk Culture Museum were crucial in identifying and protecting the architectural heritage of the Rzeszowiacy people. Today, they are still proud of their local architectural tradition, whose achievements have been preserved not only in archival documentation, but most importantly in the form of specific works of architecture displayed at the Ethnographic Park. The Rzeszowiacy can thus be certain that the buildings erected by their ancestors shall bring joy to generations to come.

\section{References}

Museum sources/Archives

Archival documents from the archives of the Folk Culture Open-Air Museum in Kolbuszowa. Field interviews from the collections of the Folk Culture Open-Air Museum in Kolbuszowa. Field notes from the collections of the Folk Culture Open-Air Museum in Kolbuszowa.

Ksiega sadowa wsi Markowa. Archives CPAHU in Lwow (1591-1777), fond 85, Part 1, Vol. 1. Manuscript. Copy in the archives of Towarzystwo Przyjaciół Markowej in Markowa.

Akta grodzkie i ziemskie z. czasów Rzeczypospolitej Polskiej z. archiwum tak zwanego bernardyńskiego we Lwowie w skutek fundacyi sp. Alexandra hr. Stadnickiego, (1878), Vol. 7, Lwow.

\section{Literature}

BARDAN, Jacek; DYPA Katarzyna (ed.), (2009). Biuletyn Jubileuszowy Mureum Kultury Ludowej w Kolbuszowej, Kolbuszowa: Wydawnictwo Mitel.

BLIN-OLBERT, Danuta (2016). Budownictwo u Lemków. In: Krzysztof Staszewski (ed.). Dawna architektura drewniana wojewódðtwa podkarpackiego. Rzeszów: Stowarzyszenie Pro Carpathia.

BYSTROŃ, Jan Stanisław (1925). Nazwy i przezwiska polskich grup plemiennych i lokalnych. In: Prace i Materialy Antropologiczno- Archeologiczne $i$ Etnograficzne, 4(3), Polska Akademia Umiejętności.

BYSTROŃ, Jan Stanisław (1925). Ugrupowania etniczne ludu polskiego (Les groupes ethnographiques polonais). Kraków: Orbis.

DRAGAN, Wojciech (2018). Budownictwo drewniane w dorzeczu środkowego Wisłoka. In: Katarzyna Barańska and Jolanta Dragan (eds.). Folklor Rzeszowiaków-obrazprzemian wedtug badań terenowych 2014-2016. Kolbuszowa: Zakład Poligraficzny Zdzisława Gajek. pp. 237258.

GINALSKI, Jerzy; OSSADNIK, Hubert (2008). 50 lat Muzeum Budownictwa Ludowego w Sanoku w świetle archiwaliów. In: Materiaty Muæeum Budownictwa Ludowego w Sanoku, 37. Sanok: Muzeum Budownictwa Ludowego.

JAWOR, Grzegorz (2000). Osady prawa wołoskiego i ich mieszkańcy na Rusi Czerwonej w późnym średniowieczu. Lublin: Wydawnictwo Uniwersytetu Marii Curie-Skłodowskiej. ISBN: 83-2272326-1.

KARCZMARZEWSKI, Andrzej (1985). Budownictwo ludowe okolic Rzeszowa. In: Krzysztof Ruszel (ed.), Prace i Materialy z Badań Etnograficznych Vol. 5. Rzeszów: Muzeum Okręgowe w Rzeszowie. 
T. Tomaszek.: The Role of the Kolbuszowa Folk Culture Open-Air Museum in Studies...

KARCZMARZEWSKI, Andrzej (1999). Grupy i regiony etnograficzne Małopolski południowo-wschodniej. In: Rzeszowska Teka Konserwatorska, 1, pp. 9-29.

KARCZMARZEWSKI, Andrzej (2012). Rzeszowiacy. Charakterystyka regionu. In: Alicja Haszczak, Tańce rzeszowskie. Rzeszów: PHU Mitel. ISBN: 9788376671215.

KOTULA, Franciszek (1951). Strój rzeszowski. In: Atlas Polskich Strojón Ludowych, 3(5), Małopolska. z.13. Lublin.

KOTULA, Franciszek (1953). Słupowe chałupy w Rzeszowskiem. In: Ochrona Zabytków, 6/4(23), pp. 211-217.

KOTULA, Franciszek (1953). Strój łańcucki. In: Atlas polskich strojów ludowych, 3(5), Małopolska. z. 5. Wrocław.

KOTULA, Franciszek (1958). Typy wiejskich drewnianych budynków na podgórzu w województwie rzeszowskim. In: Ochrona Zabytków, 11, 1-2 (40-41), pp. 35-57.

KOTULA, Franciszek (1962). Z Sandomierskiej Puszczy: gawedy kulturowo-obyczajowe. Kraków: Wydawnictwo Literackie.

KOTULA, Franciszek (1968). Geneza regionów etnograficznych woj. Rzeszonskiego. Mielec.

KOTULA, Franciszek (1974). Po Rz̨eszowskim Podgórzu bładzqc. Kraków: Wydawnictwo Literackie.

LEPUCKI, Henryk (1938). Działalność kolonizacyjna Marii Teresy i Józefa II w Galicji 1772_ 1790. In: Franciszek Bujak (ed.). Badania z Driejów Spokecznych i Gospodarczych, nr 29. Wydano z Zasiłku Zwrotnego Ministerstwa Wyznań Religijnych i Oświecenia Publicznego. Lwów.

LEW, Stefan (2003). Budownictwo ludowe dorzecza Sanu w XIX i XX wieku. Rzeszów: Mitel.

LEW, Stefan (2009). Wędrówka—czyli rzecz o pierwszym zabytku w Parku Etnograficznym. In: Jacek Bardan; Katarzyna Dypa (eds.). Biuletyn Jubileuszowy Mureum Kultury Ludowej w Kolbuszowej. Kolbuszowa: Mitel. pp. 24-32.

MOSZYŃSKI, Kazimierz (2018). Kultura ludowa Stowian. Part I.: Kultura Materialna. Warszawa: Wydawnictwo Graf_ika.

PERSOWSKI, Franciszek (1931). Księga sądowa wsi Markowej w powiecie przeworskim. In: Roczniki Driejón Spotecznych i Gospodarczych, Vol. l. Rzeszów.

PODGÓRSKI, Antoni Maria (1857). Dwa szczególne znamiona budownictwa w Rzeszowskiem. Rzeszów.

PRARAT, Maciej (2013). Koncepcja Olęderskiego Parku Etnograficznego w Wielkiej Nieszawce. Głos w dyskusji o roli skansenów w ochronie zabytków architektury drewnianej. In: Ochrona Zabytków, 1(4), pp. 235-265.

RENTZHOG, Sten (2008). Open Air Museums - the History and Future of a Visionary Idea. In: European Journal of Archaeology, 11(2-3), pp. 313-315.

RUSZEL, Krzysztof (1985). Z badań nad kulturą ludową Rzeszowiaków. In: Prace i Materiały z. Badań Etnograficznych, 5.

RUSZEL, Krzysztof (2004). Leksykon kultury ludowej w Rzeszowskiem. Stowarzyszenie Naukowe Archeologów Polskich. Rzeszów: Muzeum Okręgowe Oddział Rzeszów. ISBN: 8388085204.

RUSZEL, Krzysztof (2009). Zanim powstał skansen-czyli kształtowanie się koncepcji oraz starania o utworzenie w latach 1970-1972. In: Jacek Bardan, Katarzyna Dypa (eds.), Biuletyn Jubileuszowy Muzeum Kultury Ludowej w Kolbuszowej. Kolbuszowa: Wydawnictwo Mitel, pp. 16-24.

SALONI, Aleksander (1897). Lud wiejski w okolicy Przeworska. In: Wista: Miesiecznik geograficzno-etnograficzny, 11, pp. 738-759. 
SALONI, Aleksander (1898). Lud wiejski w okolicy Przeworska. In: Wisła: Miesiecznik geografic₹no-etnografic₹ny, 12, pp. 47-64; 719-748.

SALONI, Aleksander (1903). Lud łańcucki. Materyały etnograficzne. In: Materyały Antropologiczno-Archeologiczne i Etnograficzne. Wydane staraniem Komisyi Antropologicznej Akademii Umiejetności w Krakowie, 6, pp. 187-204.

SALONI, Aleksander (1908). Lud rzeszowski. In: Materyały Antropologiczno-Archeologiczne $i$ Etnograficzne, Wydane staraniem Komisyi Antropologicznej Akademii Umiejętności w Krakowie, 10, pp. 273-568.

SKOWROŃSKI, Maciej (2009). Tak się zaczęło..._-czyli o początkach i pierwszych latach Muzeum w Kolbuszowej. In: Jacek Bardan, Katarzyna Dypa (eds.), Biuletyn Jubileuszony Muгеum Kultury Ludowej w Kolbuszowej. Kolbuszowa: Wydawnictwo Mitel, pp. 10-16.

Stownik Geograficzny Królestwa Polskiego i krajów stowiańskich (1885). Vol. 6. (ed.: F. Chlebowski; W. Walewski). Warszawa: Nakładem Filipa Sulimierskiego i Władysława Walewskiego. 1880_ 1914.

SPISS, Anna (1985). Muzea etnograficzne na wolnym powietrzu w Europie. In: Biblioteka Muzealnictwa i Ochrony Zabytków. Studia i Materiały. Vol. II. Warszawa: Ośrodek Dokumentacji Zabytków.

STAROWOLSKI, Szymon (2000). Polska albo opisanie potożenia Królestwa Polskiego w Kolonii u Henryka Krithiusa roku 1632. (translation: Piskadło Andrzej). Gdańsk: Wydawnictwo Literackie.

STYŚ, Wincenty (1947). Drogi postępu gospodarczego wsi. Studium sz̨czegótowe na prayykeładzie zbiorowości próbnej wsi Husów. Wrocław: Wrocławskie Towarzystwo Naukowe.

SZMYGIN, Bogusław (2000). Kształtowanie koncepcji zabytku i doktryny konserwatorskiej w Polsce w XX wieku. Lublin: Wydawnictwo Politechniki Lubelskiej.

ŚWIDER, Witold (2020). Kultura ludowa Rzeszowiaków przełomu XIX i XX wiekuwybrane zagadnienia. In: Prace Historyczno-Archiwalne, 32, pp. 31-50. Archiwum Państwowe w Rzeszowie. Rzeszów: Polskie Towarzystwo Historyczne Oddział w Rzeszowie. ISSN: 1231-3335.

ŚWIECH, Jan; TUBAJA, Roman (2006). Historia idei muzealnictwa na wolnym powietrzu w Polsce. In: Biuletyn Stowarayszenia Muzeów na Wolnym Powietrzu w Polsce, 9, pp. 57-65.

TEJCHMA, Józef (2008). Dawniej. O ludziach i czasach w Markowej. Markowa.

TŁOCZEK, Ignacy (1958). Chatupy polskie. Warszawa: Arkady.

ZUBRZYCKI, Denys (1848). Granice miedzy Ruskimi polskim narodem w Galicyi. Lwów. 